\title{
New Nardosinanes and 19-0xygenated Ergosterols from the Soft Coral Nephthea armata Collected in Taiwan
}

\author{
Ali A. H. El-Gamal, ${ }^{\dagger}+$ Shang-Kwei Wang, ${ }^{\S}$ Chang-Feng Dai, ${ }^{\perp}$ and Chang-Yih Duh*,t \\ Department of Marine Resources, National Sun Yat-sen University, Kaohsiung, Taiwan, Department of Microbiology, \\ Kaohsiung Medical University, Kaohsiung, Taiwan, and Institute of Oceanography, National Taiwan University, \\ Taipei, Taiwan, Republic of China
}

Received March 26, 2004

Five new nardosinane sesquiterpenoids, armatins A-E (1-5), lemnal-1(10)-ene-2,12-dione (6) (a new natural product), and two new cytotoxic 19-oxygenated ergosterols, armatinols A and B (7 and 8), were isolated from the methylene chloride extract of the soft coral Nephthea armata, collected in Taiwan. The structures were elucidated by ID and 2D NMR spectral analysis, and their cytotoxicity was determined against selected cancer cells.

The soft corals of the genus Nephthea are rich in terpenoids $^{1-11}$ and steroids. ${ }^{12}$ As part of our search for bioactive substances from marine organisms, the soft coral Nephthea armata Thomson and Dean (family Nephtheidae), collected in Taiwan, was studied because its $\mathrm{CH}_{2-}$ $\mathrm{Cl}_{2}$ extract showed significant cytotoxicity to A549 (human lung adenocarcinoma), HT-29 (human colon adenocarcinoma), and P-388 (mouse Iymphocytic leukemia) cell cultures, as determined by standard procedures. ${ }^{13,14}$ Bioassay-guided fractionation resulted in the isolation of five new nardosinane sesquiterpenoids, armatins $A-E(\mathbf{1}-\mathbf{5})$, the new natural product lemnal-1(10)-ene-2,12-dione (6), and two new cytotoxic 19-oxygenated ergosterols, armatinols $A$ and $B$ (7 and $\mathbf{8}$ ).

\section{Results and Discussion}

Armatin A (1) was isolated as a colorless amorphous solid. HREIMS, ${ }^{13} \mathrm{C}$ NMR, and DEPT spectra established the molecular formula of $\mathbf{1}$ as $\mathrm{C}_{15} \mathrm{H}_{24} \mathrm{O}_{3}$. Thus, four degrees of unsaturation were determined for $\mathbf{1}$. The ${ }^{13} \mathrm{C} N M R$ and DEPT spectra of $\mathbf{1}$ exhibited signals for three methyls, three $\mathrm{sp}^{3}$ methylenes, six $\mathrm{sp}^{3}$ methines, one $\mathrm{sp}^{2}$ methine, one $\mathrm{sp}^{3}$ quaternary carbon, and one $\mathrm{sp}^{2}$ quaternary carbon. The presence of a secondary hydroxyl group in $\mathbf{1}$ was indicated from the IR $\left(3450 \mathrm{~cm}^{-1}\right)$ and NMR data $\left(\delta_{\mathrm{H}} 3.95\right.$ $\mathrm{m} ; \delta_{\mathrm{C}} 63.5 \mathrm{~d}$ ) (Tables 1 and 2). The presence of two $\mathrm{sp}^{2}$ hybridized carbon atoms in the molecule, as deduced from the ${ }^{13} \mathrm{C}$ and DEPT NMR spectra (Table 2), corresponding to one carbon-carbon double bond as the only multiple bond, indicated compound $\mathbf{1}$ to be tricyclic. The ${ }^{1} \mathrm{H}$ NMR spectrum contained signals for three methyl groups, two doublets $\left(\delta_{\mathrm{H}} 0.98,1.25\right)$, and one singlet $\left(\delta_{\mathrm{H}} 0.97\right)$. In addition, a signal at $\delta_{\mathrm{H}} 5.03$ was attributed to a proton on a carbon carrying two oxygens and confirmed by ${ }^{13} \mathrm{C} N \mathrm{NR}$ spectroscopy $\left(\delta_{\mathrm{C}} 107.0 \mathrm{~d}\right)$. The presence of another carbon bearing an oxygen $\left(\delta_{C} 76.3 \mathrm{~d}\right)$ was shown in the ${ }^{13} \mathrm{C} N \mathrm{NM}$ spectrum. The spectral data of $\mathbf{1}$ exhibited some similarities to those of a nardosinane sesquiterpene hemiacetal isolated from Lemnalia africana. ${ }^{15}$ Measurement of the ${ }^{13} \mathrm{C}-{ }^{13} \mathrm{C}$ homonuclear shift correlation 2D NMR spectrum (INADEQUATE) (Figure S1) of $\mathbf{1}$ together with COSY, HMQC,

* To whom correspondence should be addressed. Tel: 886-7-525-2000, ext. 5036. Fax: 886-7-525-5020. E-mail: yihduh@mail.nsysu.edu.tw.

+ National Sun Yat-sen University.

₹ On leave from the Faculty of Pharmacy, Mansoura University, Egypt.

$\S$ Kaohsiung Medical University.

$\perp$ National Taiwan University.

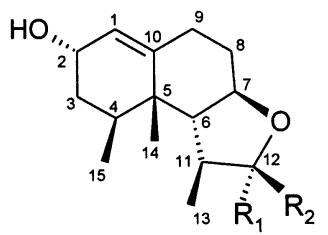

$$
\begin{array}{ll}
1 & \mathrm{R}_{1}=\mathrm{OH}, \mathrm{R}_{2}=\mathrm{H} \\
2 & \mathrm{R}_{1}, \mathrm{R}_{2}=\mathrm{O} \\
3 & \mathrm{R}_{1}=\mathrm{OMe}, \mathrm{R}_{2}=\mathrm{H}
\end{array}
$$

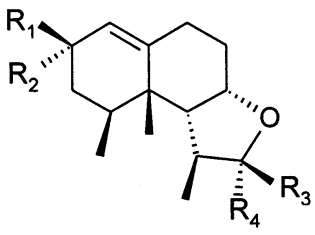

$$
\begin{aligned}
& 4 R_{1}=H, R_{2}=O H, R_{3}=O M e, R_{4}=H \\
& 5 R_{1}, R_{2}=O, R_{3}=O M e, R_{4}=H \\
& 6 R_{1}, R_{2}=O, R_{3}, R_{4}=O
\end{aligned}
$$

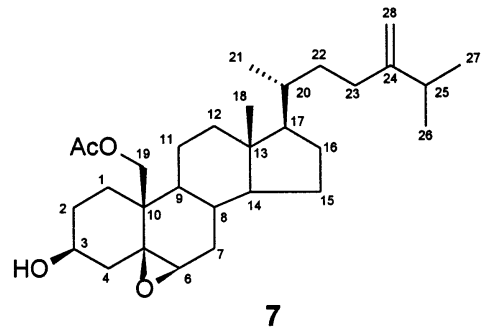

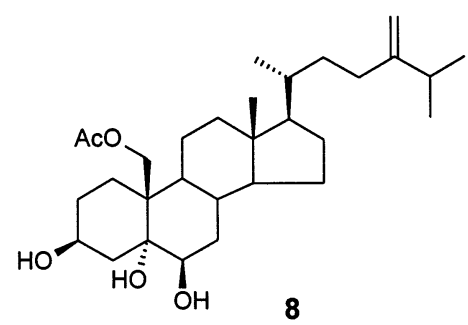

and HMBC (Table S1) experiments established its entire carbon skeleton and enabled also the assignment of all resonances in the ${ }^{13} \mathrm{C}$ NMR spectra. The $\alpha$-configuration of hydroxy at C-2 was determined by comparison with $\mathrm{J} 1,2$ of lemnacarol $\left(\mathrm{J}_{1,2}=6 \mathrm{~Hz}\right)$ and its 2-epimeric analogues 
Table 1. ${ }^{1} \mathrm{H}$ NMR Data of $1-6^{a}$

\begin{tabular}{|c|c|c|c|c|c|c|}
\hline $\mathrm{H}$ & 1 & 2 & 3 & 4 & 5 & 6 \\
\hline 1 & $5.50 \mathrm{~d}(4.5)$ & $5.60 \mathrm{~d}(4.8)$ & $5.54 \mathrm{~d}(4.5)$ & $5.49 \mathrm{~d}(4.2)$ & $5.81 \mathrm{br} \mathrm{s}$ & $5.97 \mathrm{br} \mathrm{s}$ \\
\hline 2 & $3.95 \mathrm{~m}$ & $4.06 \mathrm{~m}$ & $4.01 \mathrm{~m}$ & $4.03 \mathrm{~m}$ & & \\
\hline 3 & $1.62 \mathrm{~m}$ & $1.71 \mathrm{~m}$ & $1.68 \mathrm{~m}$ & $1.77 \mathrm{~m}$ & $2.33 \mathrm{~m}$ & $2.37 \mathrm{~m}$ \\
\hline 4 & $2.08 \mathrm{~m}$ & $2.02 \mathrm{~m}$ & $2.06 \mathrm{~m}$ & $1.97 \mathrm{~m}$ & $2.34 \mathrm{~m}$ & $2.34 \mathrm{~m}$ \\
\hline 6 & $1.53 \mathrm{~m}$ & 1.91 t (12.3) & $1.59 \mathrm{~m}$ & $1.98 \mathrm{~m}$ & $2.14 \mathrm{~m}$ & $2.61 \mathrm{~m}$ \\
\hline 7 & $3.97 \mathrm{~m}$ & $4.01 \mathrm{~m}$ & $3.80 \mathrm{~m}$ & $3.76 \mathrm{~m}$ & $3.80 \mathrm{~m}$ & $4.89 \mathrm{~m}$ \\
\hline $8 \alpha$ & $2.07 \mathrm{~m}$ & $2.29 \mathrm{~m}$ & $2.09 \mathrm{~m}$ & $1.56 \mathrm{~m}$ & $1.76 \mathrm{~m}$ & $1.80 \mathrm{~m}$ \\
\hline $8 \beta$ & $1.52 \mathrm{~m}$ & $1.68 \mathrm{~m}$ & $1.53 \mathrm{~m}$ & $2.11 \mathrm{~m}$ & $2.20 \mathrm{~m}$ & $2.25 \mathrm{~m}$ \\
\hline $9 \alpha$ & $1.98 \mathrm{dd}(18.8,10.2)$ & $2.09 \mathrm{~m}$ & $2.01 \mathrm{~m}$ & $2.02 \mathrm{~m}$ & $2.22 \mathrm{~m}$ & $2.38 \mathrm{~m}$ \\
\hline $9 \beta$ & $2.46 \mathrm{dd}(18.8,12.0)$ & $2.53 \mathrm{dd}(18.5,10.5)$ & $2.51 \mathrm{~m}$ & $2.54 \mathrm{~m}$ & $2.73 \mathrm{~m}$ & $2.59 \mathrm{~m}$ \\
\hline 11 & $2.13 \mathrm{~m}$ & $2.59 \mathrm{dq}(12.3,6.3)$ & $2.20 \mathrm{~m}$ & $2.20 \mathrm{~m}$ & $2.18 \mathrm{~m}$ & $2.37 \mathrm{~m}$ \\
\hline 12 & $5.03 \mathrm{~d}(3.3)$ & & $4.63 \mathrm{~d}(3.3)$ & $4.75 \mathrm{~d}(5.1)$ & $4.77 \mathrm{~d}(4.7)$ & \\
\hline 13 & $1.25 d(6.6)$ & $1.42 \mathrm{~d}(6.9)$ & $1.27 \mathrm{~d}(6.6)$ & $1.17 \mathrm{~d}(6.6)$ & $1.20 \mathrm{~d}(6.0)$ & $1.40 \mathrm{~d}(6.9)$ \\
\hline 14 & $0.97 \mathrm{~s}$ & $1.05 \mathrm{~s}$ & $1.00 \mathrm{~s}$ & $1.02 \mathrm{~s}$ & $1.21 \mathrm{~s}$ & $1.24 \mathrm{~s}$ \\
\hline 15 & $0.98 d(6.0)$ & $1.00 \mathrm{~d}(6.3)$ & $1.00 \mathrm{~d}(6.3)$ & $1.03 \mathrm{~d}(6.0)$ & $1.12 \mathrm{~d}(5.7)$ & $1.04 \mathrm{~d}(6.0)$ \\
\hline $\mathrm{OMe}$ & & & $3.36 \mathrm{~s}$ & $3.35 \mathrm{~s}$ & $3.63 \mathrm{~s}$ & \\
\hline
\end{tabular}

a Recorded in $\mathrm{CDCl}_{3}$ at $300 \mathrm{MHz}$.

Table 2. ${ }^{13} \mathrm{C}$ NMR Spectral Dataa $(\delta)$ of $\mathbf{1 - 6}$ in $\mathrm{CDCl}_{3}$

\begin{tabular}{lrrrrrr}
\hline & \multicolumn{1}{c}{$\mathbf{1}$} & \multicolumn{1}{c}{$\mathbf{2}$} & \multicolumn{1}{c}{$\mathbf{3}$} & \multicolumn{1}{c}{$\mathbf{4}$} & \multicolumn{1}{c}{$\mathbf{5}$} & \multicolumn{1}{c}{$\mathbf{6}$} \\
\hline 1 & 123.3 & 124.5 & 123.2 & 123.1 & 125.6 & 128.0 \\
2 & 63.5 & 63.6 & 63.8 & 63.9 & 196.9 & 197.8 \\
3 & 38.0 & 37.6 & 37.8 & 38.1 & 43.7 & 41.6 \\
4 & 26.3 & 26.1 & 26.4 & 26.1 & 32.9 & 35.6 \\
5 & 40.3 & 40.6 & 40.2 & 41.0 & 42.3 & 42.3 \\
6 & 59.9 & 56.7 & 59.6 & 54.8 & 54.8 & 49.4 \\
7 & 76.3 & 75.4 & 76.4 & 78.7 & 78.1 & 75.0 \\
8 & 29.8 & 29.3 & 29.6 & 32.0 & 31.2 & 27.2 \\
9 & 27.4 & 26.6 & 27.5 & 27.9 & 29.0 & 27.9 \\
10 & 147.8 & 146.6 & 148.5 & 149.6 & 173.4 & 165.1 \\
11 & 44.1 & 38.7 & 42.8 & 40.6 & 40.8 & 36.9 \\
12 & 107.0 & 179.4 & 113.8 & 108.9 & 108.8 & 179.8 \\
13 & 18.6 & 16.2 & 18.6 & 13.6 & 13.3 & 18.0 \\
14 & 19.9 & 19.3 & 20.0 & 19.3 & 19.0 & 19.0 \\
15 & 18.9 & 17.7 & 19.0 & 18.3 & 18.2 & 15.5 \\
OMe & & & 55.6 & 54.9 & 54.8 &
\end{tabular}

a Recorded in $\mathrm{CDCl}_{3}$ at $75 \mathrm{MHz}$ (assigned by DEPT, COSY, HSQC, and HMBC experiments).

$\left(\mathrm{J}_{1,2}=0 \mathrm{~Hz}\right){ }^{15}$ The relative stereochemistry of $\mathbf{1}$ was deduced from a 2D NOE SY experiment (Table S2), which indicated that $\mathrm{Me}-13, \mathrm{Me}-14, \mathrm{Me}-15, \mathrm{H}-6$, and $\mathrm{H}-12$ are on one side of the molecule, while $\mathrm{H}-4, \mathrm{H}-7$, and $\mathrm{H}-11$ are on the opposite side of the molecule. From the aforementioned data, armatin A can be formulated as (7 $\alpha \mathrm{H})$-lemnal-1(10)ene-2 $\alpha, 12 \alpha$-diol.

Armatin B (2) was isolated as a colorless amorphous solid, whose molecular formula, $\mathrm{C}_{15} \mathrm{H}_{22} \mathrm{O}_{3}$, was revealed by HREIMS and NMR spectra. The IR spectrum showed the presence of a lactone $\left(1745 \mathrm{~cm}^{-1}\right)$ and a secondary hydroxyl group (3515 cm-1). The ${ }^{13} \mathrm{C}$ NMR features (Table 2) of $\mathbf{2}$ closely resembled those of $\mathbf{1}$ except that the resonances for the hemiacetal in $\mathbf{1}$ were replaced by those of a $\gamma$-lactone in 2. $\mathrm{HMBC}$ correlations from $\mathrm{H}-13$ to $\mathrm{C}-6 / \mathrm{C}-11 / \mathrm{C}-12$; from $\mathrm{H}-6$ to $\mathrm{C}-5 / \mathrm{C}-7 / \mathrm{C}-8 / \mathrm{C}-13 / \mathrm{C}-14$; and from $\mathrm{H}-11$ to $\mathrm{C}-5 / \mathrm{C}-6 /$ $\mathrm{C}$-13 confirmed the position of the $\gamma$-lactone in $\mathbf{2}$. The $\alpha$-configuration of hydroxy at C-2 was determined by comparison with $J 1,2$ of lemnacarol and its 2-epimeric anal ogues. ${ }^{15}$ The relative stereochemistry of $\mathbf{2}$ was deduced from a 2D NOESY experiment (Table S2), which indicated that $\mathrm{Me}-13, \mathrm{Me}-14, \mathrm{Me}-15$, and $\mathrm{H}-6$ are on one side of the molecule, while $\mathrm{H}-4, \mathrm{H}-7$, and $\mathrm{H}-11$ are on the opposite side of the molecule (Figure 1). From the aforementioned data, amatin B was formulated as $2 \alpha$-hydroxy-( $7 \alpha \mathrm{H})$-lemnal1(10)-en-12-one.

Armatin $\mathrm{C}$ (3) had the molecular formula $\mathrm{C}_{16} \mathrm{H}_{26} \mathrm{O}_{3}$, as determined by HREIMS and NMR spectral data (Tables 1 and 2). The EIMS and NMR spectra showed that $\mathbf{3}$ is a O-methyl derivative of $\mathbf{1}$. The NMR chemical shifts of $\mathbf{3}$

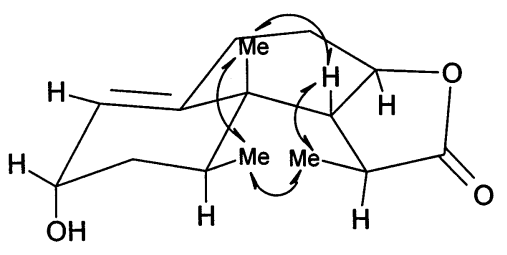

Figure 1. Key NOESY correlations of 2.

were very close to those of $\mathbf{1}$ except that the hydroxyl was replaced by a methoxyl group at $\mathrm{C}-12$. HMBC correlations (Table S1) from $\mathrm{H}-12$ and $\mathrm{C}-6 / \mathrm{C}-7 / \mathrm{C}-11 / \mathrm{C}-13 / \mathrm{OCH}_{3}$ and from $\mathrm{H}-11$ to $\mathrm{C}-5 / \mathrm{C}-12 / \mathrm{C}-13 / \mathrm{OCH}_{3}$ enable the correct positioning of the methoxyl group. The $\alpha$-configuration of hydroxy at C-2 was determined by comparison with J 1,2 of lemnacarol and its 2-epimeric analogues. ${ }^{15}$ The relative stereochemistry of $\mathbf{3}$ was deduced from a 2D NOESY experiment (Table S2), which indicated that Me-13, Me$14, \mathrm{Me}-15, \mathrm{H}-6$, and $\mathrm{H}-12$ are on one side of the molecule, while $\mathrm{H}-4, \mathrm{H}-7$, and $\mathrm{H}-11$ are on the opposite side of the molecule. The structure of armatin C (3) was thus formulated as $12 \alpha$-methoxy-( $7 \alpha \mathrm{H})$-lemnal-1(10)-en-2 $\alpha$-ol.

Armatin D (4) analyzed for $\mathrm{C}_{16} \mathrm{H}_{26} \mathrm{O}_{3}$ by HREIMS and NMR spectral data. The IR spectrum showed the presence of a hydroxyl $\left(3450 \mathrm{~cm}^{-1}\right)$ group. The EIMS and NMR spectra showed that $\mathbf{4}$ is a stereoisomer of $\mathbf{3}$. The spectroscopic data of $\mathbf{4}$ were similar to those of $\mathbf{3}$ with the exception of signals in the vicinity of the five-membered ring. The $\alpha$-configuration of the hydroxy at C- 2 was determined by comparison with $\mathrm{J}_{1,2}$ of lemnacarol and its 2-epimeric analogues. ${ }^{15}$ The relative ster eochemistry of $\mathbf{4}$ was deduced from a 2D NOESY experiment (Table S2), which indicated that $\mathrm{Me}-13, \mathrm{Me}-14, \mathrm{Me}-15, \mathrm{H}-6, \mathrm{H}-7$, and OMe are on one side of the molecule, while $\mathrm{H}-4, \mathrm{H}-11$, and $\mathrm{H}-12$ are on the opposite side of the molecule. The structure of armatin D was thus formulated as $12 \beta$-methoxylemnal-1(10)-en-2 $\alpha$ ol.

Armatin E (5) was isolated as a colorless amorphous solid of molecular formula $\mathrm{C}_{16} \mathrm{H}_{24} \mathrm{O}_{3}$, as indicated by HREIMS and ${ }^{13} \mathrm{C}$ NMR (Table 2) spectral methods. The spectroscopic data of $\mathbf{5}$ were analogous to those of $\mathbf{4}$ with the exception that the resonances for the secondary hydroxyl in $\mathbf{4}$ were replaced by those of a ketone in 5 . HMBC correlations (Table S1) from $\mathrm{H}-1$ to $\mathrm{C}-2 / \mathrm{C}-3 / \mathrm{C}-9$; from $\mathrm{H}-3$ to $\mathrm{C}-2 / \mathrm{C}-1$; and from $\mathrm{H}-4$ to $\mathrm{C}-2 / \mathrm{C}-3 / \mathrm{C}-6$ hel ped ascertain the position of the $\alpha, \beta$-unsaturated ketone group. The relative stereochemistry of $\mathbf{5}$ was deduced from a 2D NOESY experiment (Table S2), which indicated that Me-13, Me-14, Me-15, H-6, $\mathrm{H}-7$, and $\mathrm{OMe}$ are on one side of the molecule, while $\mathrm{H}-4$, $\mathrm{H}-11$, and $\mathrm{H}-12$ are on the opposite side of the molecule. 


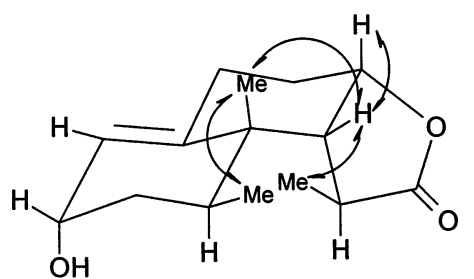

Figure 2. Key NOESY correlations of 6.

The structure of armatin E was thus formulated as $12 \beta$ methoxylemnal-1(10)-en-2-one.

Compound 6 was isolated as a colorless amorphous solid and analyzed for $\mathrm{C}_{15} \mathrm{H}_{20} \mathrm{O}_{3}$ by HREIMS and NMR spectral data (Tables 1 and 2). The ${ }^{13} \mathrm{C}$ NMR features (Table 2) of $\mathbf{6}$ closely resembled those of $\mathbf{5}$, except the resonances for the methoxyl in $\mathbf{5}$ were replaced by a carbonyl in $\mathbf{6}$. HMBC correlations from $\mathrm{H}-13$ to $\mathrm{C}-6 / \mathrm{C}-11 / \mathrm{C}-12$; from $\mathrm{H}-6$ to $\mathrm{C}-5 /$ C-7/C-13/C-14; and from H-11 to C-5/C-6/C-13 confirmed the position of the lactone in $\mathbf{6}$. The relative stereochemistry of $\mathbf{6}$ was deduced from a 2D NOESY experiment (Table S2), which indicated that Me-13, Me-14, Me-15, H-6, and $\mathrm{H}-7$ were on one side of the molecule, while $\mathrm{H}-4$ and $\mathrm{H}$-11 were on the opposite side of the molecule (F igure 2). The ${ }^{1} \mathrm{H}$ NMR data of $\mathbf{6}$ were identical with those of lemnal1(10)-ene-2,12-dione, a J ones oxidation product of lemnal1 (10)-ene- $2 \beta, 12 \beta$-diol, which was isolated from the soft coral Lemnaol africana. ${ }^{15}{ }^{13} \mathrm{C}$ NMR data and detailed assignments of ${ }^{1} \mathrm{H}$ NMR data of $\mathbf{6}$ were not reported previously.

Armatinol A (7) was assigned a molecular formula of $\mathrm{C}_{30} \mathrm{H}_{48} \mathrm{O}_{4}$, as indicated by HREIMS. The ${ }^{13} \mathrm{C}$ NMR and DEPT spectra of $\mathbf{7}$ exhibited the presence of signals for four methyls, $10 \mathrm{sp}^{3}$ methylenes, eight $\mathrm{sp}^{3}$ methines, one $\mathrm{sp}^{2}$ methylene, three $\mathrm{sp}^{3}$ quaternary carbons, and one $\mathrm{sp}^{2}$ quaternary carbon. The presence of a terminal methylene was indicated by the ${ }^{1} \mathrm{H}$ NMR $[\delta 4.66(1 \mathrm{H}, \mathrm{s}), 4.72(1 \mathrm{H}, \mathrm{s})]$ and the ${ }^{13} \mathrm{C}$ NMR $[\delta 106.0(\mathrm{CH}), 156.9$ (C)] spectra. The IR absorption at $1730 \mathrm{~cm}^{-1}$ and the ${ }^{1} \mathrm{H}$ NMR signal at $\delta 3.79$ $(1 \mathrm{H}, \mathrm{m})$ as well as the ${ }^{13} \mathrm{C} N M R$ signal at $\delta 68.8(\mathrm{CH})$ indicated the presence of a secondary hydroxyl group. The presence of a primary acetoxy group was indicated by ${ }^{1} \mathrm{H}$ NMR [ $4.08(1 \mathrm{H}, \mathrm{d}, \mathrm{J}=11.4 \mathrm{~Hz}), 4.46(1 \mathrm{H}, \mathrm{d}, \mathrm{J}=11.4$ $\mathrm{Hz})$, and $2.10(3 \mathrm{H}, \mathrm{s})]$ and ${ }^{13} \mathrm{C} N \mathrm{NMR}\left[\delta 66.0\left(\mathrm{CH}_{2}\right), 21.4\right.$ $\left.\left(\mathrm{CH}_{3}\right), 171.1(\mathrm{C})\right]$ spectra. The ${ }^{13} \mathrm{C}$ NMR signals at $\delta 61.4$ $(\mathrm{CH})$ and $61.0(\mathrm{C})$ and ${ }^{1} \mathrm{H} N M R$ signal at $\delta 2.98(1 \mathrm{H}, \mathrm{br} \mathrm{s})$ showed the presence of a trisubstituted epoxy ring. The spectral data of $\mathbf{7}$ exhibited some similarities to values for 5,6-epoxylitosterol, ${ }^{16}$ except for the presence of a primary acetoxy in 7 instead of a primary hydroxy in 5,6-epoxylitosterol. The placement of the acetoxy group at C-19 was made on the basis of $\mathrm{HMBC}$ correlations from $\mathrm{H}-19$ to $\mathrm{C}-5 /$ C-9/C-10 and from $\mathrm{H}_{3}-\mathrm{OAC}$ to the ester carbonyl carbon. The epoxy group was placed at C -5 and $\mathrm{C}-6$ on the basis of ${ }^{1} \mathrm{H}-{ }^{1} \mathrm{H}$ COSY correlations from $\mathrm{H}-6$ to $\mathrm{H}-7$ and from $\mathrm{H}-7$ to $\mathrm{H}-8$ and $\mathrm{HMBC}$ correlations from $\mathrm{H}-3$ to $\mathrm{C}-2 / \mathrm{C}-5$ and from $\mathrm{H}-6$ to $\mathrm{C}-4 / \mathrm{C}-7 / \mathrm{C}-8$. The NOE SY correlations (Figure 3) observed between $\mathrm{H}_{2}-19$ and $\mathrm{H}-8 / \mathrm{H}-12 \beta ; \mathrm{H}-4 \alpha$ and $\mathrm{H}-6 /$ $\mathrm{H}-3 ; \mathrm{H}-3$ and $\mathrm{H}-1 \alpha / \mathrm{H}-2 ; \mathrm{H}-9$ and $\mathrm{H}-7 \alpha / \mathrm{H}-14 ; \mathrm{H}_{3}-18$ and $\mathrm{H}-20 / \mathrm{H}-8 / \mathrm{H}-12 \beta$; and $\mathrm{H}_{3}-21$ and $\mathrm{H}-12 \beta$ indicated the relative configurations for each ring junction and chiral center. The stereochemistry at C-20 was confirmed by comparison of ${ }^{13} \mathrm{C}$ NMR data with those of 5,6-epoxylitosterol. ${ }^{16}$ The structure of armatinol A was thus formulated as 19acetoxy-5 $\beta, 6 \beta$-epoxy-24-methylenecholestan-3 $\beta$-ol.

HREIMS and ${ }^{13} \mathrm{C}$ NMR data revealed armatinol B (8) to have a molecular formula of $\mathrm{C}_{30} \mathrm{H}_{50} \mathrm{O}_{5}$. The ${ }^{13} \mathrm{C}$ and ${ }^{1} \mathrm{H}$ NMR data showed some similarities to those of 7, except for the presence of two additional hydroxyls and the

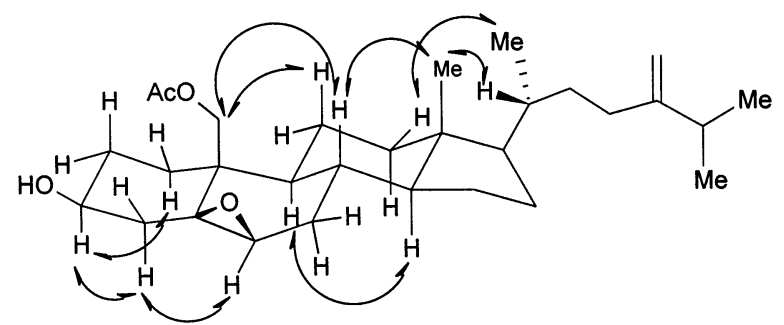

Figure 3. Key NOESY correlations of 7.

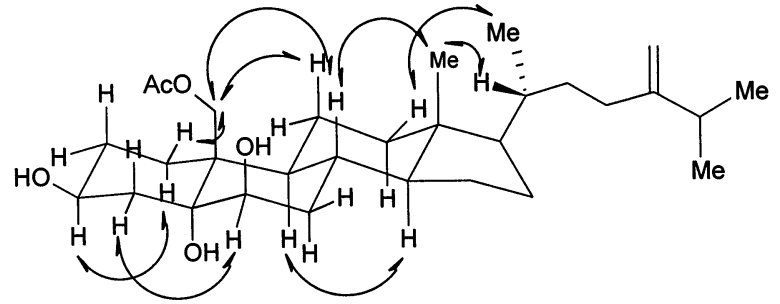

Figure 4. Key NOESY correlations of 8.

absence of a trisubstituted epoxy unit. The location of the hydroxyls on $\mathrm{C}-5$ and $\mathrm{C}-6$ was made on the basis of ${ }^{1} \mathrm{H}-{ }^{1} \mathrm{H}$ COSY correlations from $\mathrm{H}-6$ to $\mathrm{H}-7$ and from $\mathrm{H}-7$ to $\mathrm{H}-8$ and $\mathrm{HMBC}$ correlations from $\mathrm{H}-3$ to $\mathrm{C}-2 / \mathrm{C}-4 / \mathrm{C}-5$ and from $\mathrm{H}-6$ to $\mathrm{C}-4 / \mathrm{C}-5 / \mathrm{C}-7 / \mathrm{C}-8$. The NOESY correlations (Figure 4) observed between $\mathrm{H}_{2}-19$ and $\mathrm{H}-8 / \mathrm{H}-1 \beta / 12 \beta ; \mathrm{H}-4 \alpha$ and $\mathrm{H}-6 / \mathrm{H}-3 ; \mathrm{H}-3$ and $\mathrm{H}-1 \alpha / \mathrm{H}-2 ; \mathrm{H}-8$ and $\mathrm{H}-7 / 3 / \mathrm{H}_{3}-18 ; \mathrm{H}-9$ and $\mathrm{H}-7 \alpha / \mathrm{H}-14 ; \mathrm{H}_{3}-18$ and $\mathrm{H}-20 / 12 \beta / \mathrm{H}-8$; and $\mathrm{H}_{3}-21$ and $\mathrm{H}-12 \beta$ indicated the relative configurations for each ring junction and chiral center. The stereochemistry at C-20 was confirmed by comparison of ${ }^{13} \mathrm{C}$ NMR data with those of 5,6epoxylitosterol. ${ }^{16}$ The structure of armatinol B was thus formulated as 19-acetoxy-24-methylenechol estan- $3 \beta, 5 \alpha, 6 \beta$ triol.

Armartnol A (7) exhibited cytotoxicity against A-549, HT29 , and P-388 cells with IC 50 value of $7.6,6.5$, and $6.1 \mu \mathrm{M}$, respectively. Armatinol $B(\mathbf{8})$ showed cytotoxicity against P-388 and HT-29 cells with IC $\mathrm{C}_{50}$ values of 3.2 and $3.1 \mu \mathrm{M}$, respectively. The $\mathrm{IC}_{50}$ values of compounds $\mathbf{1 - 6}$ against P-388, HT-29, and A-549 were greater than $50 \mu \mathrm{M}$.

\section{Experimental Section}

General Experimental Procedures. Melting points were determined using a Yanagimoto micromelting point apparatus and are reported uncorrected. Optical rotations were determined on a J ASCO DIP-181 polarimeter. UV spectra were obtained on a Shimadzu UV-160A spectrophotometer, and IR spectra were recorded on a Hitachi 26-30 spectrophotometer. The NMR spectra were recorded on a Bruker Avance 300 NMR spectrometer at $300 \mathrm{MHz}$ for ${ }^{1} \mathrm{H}$ and $75 \mathrm{MHz}$ for ${ }^{13} \mathrm{C}$, respectively, in $\mathrm{CDCl}_{3}$ using TMS as internal standard. The EIMS were obtained with a JEOL J MS-SX/SX 102A mass spectrometer at $70 \mathrm{eV}$. Si gel 60 (Merck, 230-400 mesh) was used for column chromatography; precoated Si gel plates (Merck, Kieselgel $60 \mathrm{~F}_{254}, 0.25 \mathrm{~mm}$ ) were used for TLC analysis.

Animal Material. The soft coral N. armata was collected at Green Island, off Taiwan, in March 2002, at a depth of $5 \mathrm{~m}$ and was stored for 1 week in a freezer until extraction. A voucher specimen, NSUGN-050, was deposited in the Department of Marine Resources, National Sun Yat-sen University, Taiwan.

Extraction and Isolation. The bodies of the soft coral N. armata were freeze-dried to give $1.75 \mathrm{~kg}$ of a solid, which was extracted with $\mathrm{CH}_{2} \mathrm{Cl}_{2}(2.0 \mathrm{~L} \times 3)$. After removal of solvent in vacuo, the residue $(27 \mathrm{~g})$ was chromatographed over Si gel 60 using n-hexane-EtOAc and $\mathrm{MeOH}-\mathrm{EtOAc}$ mixtures as el uting solvents. Elution by n-hexane-EtOAc (3:7) afforded frac- 
tions containing $\mathbf{1}, \mathbf{3}-\mathbf{5}$, and $\mathbf{8}$. Elution by $\mathrm{MeOH}-\mathrm{EtOAC}$ (5:95) afforded fractions containing 2, 6, and 7. Compound $\mathbf{1}$ was further purified by $\mathrm{Si}$ gel column chromatography, by eluting with $\mathrm{MeOH}-\mathrm{CH}_{2} \mathrm{Cl}_{2}$ (12:88). Compound 8 was further purified by $\mathrm{Si}$ gel column chromatography, by eluting with $\mathrm{MeOH}-\mathrm{CH}_{2} \mathrm{Cl}_{2}$ (25:75). Compounds 3-5 were further purified by $\mathrm{C}_{18} \mathrm{HPLC}$ column chromatography, by eluting with $\mathrm{MeOH}-$ $\mathrm{H}_{2} \mathrm{O}$ (67:33). Compound 2 was further purified by Si gel column chromatography, with n-hexane-EtOAc (1:1) used as solvent. Compound $\mathbf{7}$ was further purified by $\mathrm{Si}$ gel column chromatography, by eluting with acetone- $\mathrm{CH}_{2} \mathrm{Cl}_{2}$ (2:8). Compound 6 was obtained by $\mathrm{C}_{18} \mathrm{HPLC}$ column, using $\mathrm{MeOH}-\mathrm{H}_{2} \mathrm{O}$ (65:35) as solvent system.

Armatin A (1): colorless amorphous solid; $[\alpha]^{25}-106^{\circ}$ (C 0.4, $\left.\mathrm{CHCl}_{3}\right)$; UV (MeOH) $\lambda_{\max }(\log \epsilon) 205$ (3.4) nm; IR (KBr) $v_{\max } 3450 \mathrm{~cm}^{-1}$; ${ }^{1} \mathrm{H}$ NMR, see Table $1 ;{ }^{13} \mathrm{C}$ NMR, see Table 2; EIMS m/z 252 [M] ] (2), 234 (8), 216 (12), 201 (18), 187, 120 (100); HREIMS m/z 252.1712 (calcd for $\mathrm{C}_{15} \mathrm{H}_{24} \mathrm{O}_{3}, 252.1719$ ).

Armatin B (2): colorless amorphous solid; $[\alpha]^{25} \mathrm{D}-243^{\circ}$ (C 0.8, $\left.\mathrm{CHCl}_{3}\right)$; UV (MeOH) $\lambda_{\max }(\log \epsilon) 207$ (3.5) nm; IR (KBr) $v_{\max } 3515,1745 \mathrm{~cm}^{-1} ;{ }^{1} \mathrm{H}$ NMR, see Table $1 ;{ }^{13} \mathrm{C}$ NMR, see Table 2; EIMS m/z 250 [M ]+ (1), 232 (5), 221 (2), 167 (28), 136 (23), 121 (50), 107 (62), 83 (100); HREI MS m/z 250.1558 (calcd for $\mathrm{C}_{15} \mathrm{H}_{22} \mathrm{O}_{3}, 250.1563$ ).

Armatin C (3): colorless amorphous solid; $[\alpha]^{25} \mathrm{D}-198^{\circ}$ (C 0.4, $\mathrm{CHCl}_{3}$ ); UV (MeOH) $\lambda_{\max }(\mathrm{log} \epsilon) 209$ (3.9) nm; IR (KBr) $v_{\max } 3385 \mathrm{~cm}^{-1}$; ${ }^{1} \mathrm{H}$ NMR, see Table $1 ;{ }^{13} \mathrm{C}$ NMR, see Table 2; EIMS m/z 266 [M] ] (3), 248 (18), 173 (35), 147 (63), 119 (78), 55 (100); HREI MS m/z 266.1870 (calcd for $\mathrm{C}_{16} \mathrm{H}_{26} \mathrm{O}_{3}, 266.1875$ ).

Armarin D (4): colorless oil; $[\alpha]^{25} \mathrm{D}-178^{\circ}$ (c $0.1, \mathrm{CHCl}_{3}$ ); UV (MeOH) $\lambda_{\max }(\log \epsilon) 204$ (3.6) nm; IR (KBr) $v_{\max } 3450 \mathrm{~cm}^{-1}$; ${ }^{1} \mathrm{H}$ NMR, see Table $1 ;{ }^{13} \mathrm{C}$ NMR, see Table 2; EIMS m/z 266 $[\mathrm{M}]^{+}$(4), 248 (26), 175 (32), 147 (60), 119 (82), 105 (76), 55 (100); HREIMS m/z 266.1868 (calcd for $\mathrm{C}_{16} \mathrm{H}_{26} \mathrm{O}_{3}, 266.1875$ ).

Armatin E (5): colorless amorphous solid; $[\alpha]^{25} \mathrm{D}-28^{\circ}$ (c $\left.0.2, \mathrm{CHCl}_{3}\right) ; \mathrm{UV}(\mathrm{MeOH}) \lambda_{\max }(\log \epsilon) 239$ (4.7) nm; IR (KBr) $v_{\max } 1730 \mathrm{~cm}^{-1}$; ${ }^{1} \mathrm{H}$ NMR, see Table $1 ;{ }^{13} \mathrm{C}$ NMR, see Table 2; EIMS m/z 264 [M] ] (3), 234 (13), 207 (18), 189 (47), 69 (100); HREIMS m/z 264.1711 (calcd for $\mathrm{C}_{16} \mathrm{H}_{24} \mathrm{O}_{3}, 264.1719$ ).

Armatin F (6): colorless amorphous solid; $[\alpha]^{25}-11^{\circ}$ (c 0.2, $\mathrm{CHCl}_{3}$ ); UV (MeOH) $\lambda_{\max }(\mathrm{log} \epsilon) 246$ (4.3) nm; IR (KBr) $v_{\max } 1750,1730 \mathrm{~cm}^{-1} ;{ }^{1} \mathrm{H} \mathrm{NMR}$, see Table $1 ;{ }^{13} \mathrm{C} \mathrm{NMR}$, see Table 2; EIMS m/z 248 [M] $]^{+}$(6), 232 (2), 206 (18), 175 (20), 133 (43), 91 (60), 69 (100); HREIMS m/z 248.1398 (calcd for $\mathrm{C}_{15} \mathrm{H}_{20} \mathrm{O}_{3}$, 248.1407).

Armatinol A (7): col orless amorphous solid; $[\alpha]^{25}-6.2^{\circ}$ (c 0.4, $\left.\mathrm{CHCl}_{3}\right)$; UV (MeOH) $\lambda_{\max }(\log \epsilon) 206$ (3.5) nm; IR $(\mathrm{KBr})$ $v_{\max } 3465,1730 \mathrm{~cm}^{-1} ;{ }^{1} \mathrm{H}$ NMR $\left(\mathrm{CDCl}_{3}, 300 \mathrm{MHz}\right) \delta 0.67(3 \mathrm{H}$, $\left.\mathrm{s}, \mathrm{H}_{3}-18\right), 0.72(1 \mathrm{H}, \mathrm{m}, \mathrm{H}-9), 0.86(1 \mathrm{H}, \mathrm{m}, \mathrm{H}-14), 0.93(3 \mathrm{H}, \mathrm{d}, \mathrm{J}$ $\left.=6.3 \mathrm{~Hz}, \mathrm{H}_{3}-21\right), 1.02\left(3 \mathrm{H}, \mathrm{d}, \mathrm{J}=6.9 \mathrm{~Hz}, \mathrm{H}_{3}-26\right), 1.03(3 \mathrm{H}, \mathrm{d}$, $\left.\mathrm{J}=6.3 \mathrm{~Hz}, \mathrm{H}_{3}-27\right), 1.04(\mathrm{H}, \mathrm{m}, \mathrm{H}-12 \alpha), 1.17(1 \mathrm{H}, \mathrm{m}, \mathrm{H}-22)$, 1.30 (1H, m, H-16), $1.32(1 \mathrm{H}, \mathrm{m}, \mathrm{H}-7 \alpha), 1.39$ (1H, $\mathrm{m}, \mathrm{H}-2 \alpha)$, $1.41(1 \mathrm{H}, \mathrm{m}, \mathrm{H}-2 \alpha), 1.43(1 \mathrm{H}, \mathrm{m}, \mathrm{H}-20), 1.45(1 \mathrm{H}, \mathrm{m}, \mathrm{H}-23)$, $1.49(1 \mathrm{H}, \mathrm{m}, \mathrm{H}-11), 1.52(1 \mathrm{H}, \mathrm{m}, \mathrm{H}-4 \alpha), 1.55(1 \mathrm{H}, \mathrm{m}, \mathrm{H}-11)$, $1.57(1 \mathrm{H}, \mathrm{m}, \mathrm{H}-22), 1.59(1 \mathrm{H}, \mathrm{m}, \mathrm{H}-8), 1.63(1 \mathrm{H}, \mathrm{m}, \mathrm{H}-15), 1.88$

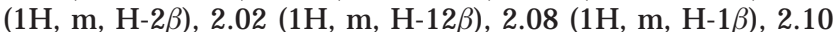
(3H, s, OAC), $2.17(1 \mathrm{H}, \mathrm{m}, \mathrm{H}-7), 2.24(1 \mathrm{H}, \mathrm{m}, \mathrm{H}-25), 2.26(1 \mathrm{H}$

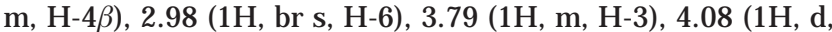
$\mathrm{J}=11.4 \mathrm{~Hz}, \mathrm{H}-19), 4.46(1 \mathrm{H}, \mathrm{J}=11.4 \mathrm{~Hz}, \mathrm{H}-19), 4.66(1 \mathrm{H}, \mathrm{s}$, $\mathrm{H}-28), 4.72(1 \mathrm{H}, \mathrm{s}, \mathrm{H}-28) ;{ }^{13} \mathrm{C} \mathrm{NMR}\left(\mathrm{CDCl}_{3}, 75 \mathrm{MHz}\right) \delta 11.8 \mathrm{q}$ (C-18), 18.7 q (C-21), $21.4 \mathrm{q}(\mathrm{OAC}), 21.9 \mathrm{q}(\mathrm{C}-26,27), 22.1 \mathrm{t}$ (C-11), 24.2 t (C-15), 28.2 t (C-16), 30.4 d (C-8), 31.0 t (C-23), $31.3 \mathrm{t}(\mathrm{C}-2), 32.5 \mathrm{t}(\mathrm{C}-1), 32.9 \mathrm{t}(\mathrm{C}-7), 33.9 \mathrm{~d}(\mathrm{C}-25), 34.7 \mathrm{t}(\mathrm{C}-$ 22), $35.8 \mathrm{~d}$ (C-20), $37.9 \mathrm{~s}(\mathrm{C}-10), 40.0 \mathrm{t}(\mathrm{C}-12), 43.4 \mathrm{t}(\mathrm{C}-13)$, $42.7 \mathrm{t}(\mathrm{C}-4), 50.2 \mathrm{~d}(\mathrm{C}-9), 56.0 \mathrm{~d}(\mathrm{C}-17), 56.5 \mathrm{~d}(\mathrm{C}-14), 61.0 \mathrm{~s}$ (C-5), 61.4 d (C-6), 66.0 t (C-19), 68.8 d (C-3), 106.0 t (C-28), $156.9 \mathrm{~s}(\mathrm{C}-25), 171.1 \mathrm{~s}(\mathrm{OAC}) ; \mathrm{EIMS} \mathrm{m} / \mathrm{z} 472$ [M] $]^{+}(2), 454$ (8), 412 (15), 396 (13), 328 (10), 310 (24), 55 (100); HREIMS m/z 472.3533 (calcd for $\mathrm{C}_{30} \mathrm{H}_{48} \mathrm{O}_{4}, 472.3540$ ).
Armatinol B (8): colorless oil; $[\alpha]^{25} \mathrm{D}-4.4^{\circ}$ (c 0.6, $\mathrm{CHCl}_{3}$ ); UV (MeOH) $\lambda_{\max }(\log \epsilon) 206$ (3.9) nm; IR (KBr) $v_{\max } 3385,1735$ $\mathrm{cm}^{-1} ;{ }^{1} \mathrm{H}$ NMR $\left(\mathrm{CDCl}_{3}, 300 \mathrm{MHz}\right) \delta 0.68\left(3 \mathrm{H}, \mathrm{s}, \mathrm{H}_{3}-18\right), 0.94$ $\left(3 \mathrm{H}, \mathrm{d}, \mathrm{J}=6.3 \mathrm{~Hz}, \mathrm{H}_{3}-21\right), 1.02\left(3 \mathrm{H}, \mathrm{d}, \mathrm{J}=6.9 \mathrm{~Hz}, \mathrm{H}_{3}-26\right)$, $1.03\left(3 \mathrm{H}, \mathrm{d}, \mathrm{J}=6.3 \mathrm{~Hz}, \mathrm{H}_{3}-27\right), 1.12(1 \mathrm{H}, \mathrm{m}, \mathrm{H}-14), 1.15(1 \mathrm{H}$, $\mathrm{m}, \mathrm{H}-12 \beta), 1.18(1 \mathrm{H}, \mathrm{m}, \mathrm{H}-17), 1.19(1 \mathrm{H}, \mathrm{m}, \mathrm{H}-22), 1.30(1 \mathrm{H}$, $\mathrm{m}, \mathrm{H}-16), 1.43(1 \mathrm{H}, \mathrm{m}, \mathrm{H}-9), 1.45$ (1H, $\mathrm{m}, \mathrm{H}-20), 1.49(1 \mathrm{H}, \mathrm{m}$, $\mathrm{H}-1 \alpha), 1.51(1 \mathrm{H}, \mathrm{m}, \mathrm{H}-11), 1.60(1 \mathrm{H}, \mathrm{m}, \mathrm{H}-22), 1.70(1 \mathrm{H}, \mathrm{m}$ $\mathrm{H}-4 \beta), 1.89(1 \mathrm{H}, \mathrm{m}, \mathrm{H}-8), 2.02(1 \mathrm{H}, \mathrm{m}, \mathrm{H}-12 \beta), 2.05(1 \mathrm{H}, \mathrm{m}$, $\mathrm{H}-1 \beta), 2.07(3 \mathrm{H}, \mathrm{s}, \mathrm{OAc}), 2.17(\mathrm{H}, \mathrm{m}, \mathrm{H}-4 \alpha), 2.18(1 \mathrm{H}, \mathrm{m}, \mathrm{H}-25)$, $3.54(1 \mathrm{H}$, br s, H-6), $4.10(1 \mathrm{H}, \mathrm{m}, \mathrm{H}-3), 4.49(1 \mathrm{H}, \mathrm{d}, \mathrm{J}=12.6$ $\mathrm{Hz}, \mathrm{H}-19), 4.61(1 \mathrm{H}, \mathrm{J}=12.6 \mathrm{~Hz}, \mathrm{H}-19), 4.66(1 \mathrm{H}, \mathrm{s}, \mathrm{H}-28)$, $4.72(1 \mathrm{H}, \mathrm{s}, \mathrm{H}-28) ;{ }^{13} \mathrm{C} \mathrm{NMR}\left(\mathrm{CDCl}_{3}, 75 \mathrm{MHz}\right) \delta 12.3 \mathrm{q}(\mathrm{C}-18)$, 18.7 q (C-21), $21.4 \mathrm{q}(\mathrm{OAC}), 21.9 \mathrm{q}(\mathrm{C}-26), 22.1 \mathrm{q}(\mathrm{C}-27), 22.3 \mathrm{t}$ (C-11), 24.1 t (C-15), 25.5 t (C-1), $28.3 \mathrm{~d}(\mathrm{C}-16), 31.7 \mathrm{~d}(\mathrm{C}-8)$, $31.0 \mathrm{t}(\mathrm{C}-23), 32.1 \mathrm{t}(\mathrm{C}-2), 33.9 \mathrm{~d}(\mathrm{C}-25), 34.1 \mathrm{t}(\mathrm{C}-7), 34.8 \mathrm{t}$ (C-22), $35.8 \mathrm{~d}(\mathrm{C}-20), 40.5 \mathrm{t}(\mathrm{C}-12), 41.2 \mathrm{t}(\mathrm{C}-4), 42.3 \mathrm{~s}(\mathrm{C}-10)$, $42.9 \mathrm{~s}(\mathrm{C}-13), 45.4 \mathrm{~d}(\mathrm{C}-9), 56.1 \mathrm{~d}(\mathrm{C}-17), 56.2 \mathrm{~d}(\mathrm{C}-14), 64.6 \mathrm{~d}$ (C-19), 67.5 d (C-3), $75.1 \mathrm{~s}(\mathrm{C}-5), 75.7 \mathrm{~d}(\mathrm{C}-6), 106.0 \mathrm{t}$ (C-28), $156.9 \mathrm{~s}(\mathrm{C}-25), 171.7 \mathrm{~s}(\mathrm{OAC}) ; \mathrm{EIMS} \mathrm{m} / \mathrm{z} 490$ [M ] $^{+}$(2), 472 (8), 430 (15), 198 (23), 69 (100); HREI MS m/z 490.3648 (cal cd for $\left.\mathrm{C}_{30} \mathrm{H}_{50} \mathrm{O}_{5}, 490.3645\right)$.

Cytotoxicity Testing. P-388 cells were kindly supplied by Dr. J . M. Pezzuto, University of Illinois at Chicago; A549 and HT-29 were purchased from the American Type Culture Collection. Cytotoxic assays were carried out according to a procedure described previously. ${ }^{14}$ Mithramycin was used as the positive control and showed cytotoxicity against A-549, HT29 , and P-388 cells with $\mathrm{IC}_{50}$ values $0.2,0.3$, and $0.1 \mu \mathrm{M}$, respectively.

Acknowledgment. We thank Dr. J . M. Pezzuto for the provision of the P-388 cell line. This work was supported by grants from the National Science Council of Taiwan awarded to C.-Y.D.

Supporting Information Available: 2D INADEQUATE NMR spectrum of $\mathbf{1}$ and tables for HMBC and NOESY correlations of 1-6 are available free of charge via the Internet at http://pubs.acs.org.

\section{References and Notes}

(1) Coll, J . C.; Bowden, B. F.; Tapiolas, D. M.; Willis, R. H. Tetrahedron 1985, 41, 1085-1092

(2) Poet, S. E.; Ravi, B. N. Aust. J . Chem. 1982, 35, 77-83.

(3) Ahond, A.; Bowden, B. F.; Coll, J . C.; Fourneron, J .; Mitchell, S. J. Aust. J . Chem. 1981, 34, 2657-2664.

(4) Blackman, A. J .; Bowden, B. F.; Coll, J. C.: Frick, B.; Mahendran, M.; Mitchell, S. j. . Aust. J. Chem. 1982, 35, 1873-1880.

(5) Kitagawa, I.; Cui, Z.; Son, B. W.; Kobayashi, M.; Kyogoku, Y. Chem Pharm. Bull. 1987, 35, 124-135.

(6) Bowden, B. F.; Coll, J. C.; Mitchell, S. J . Aust. J . Chem. 1980, 33, $1833-1839$

(7) Handayani, D.; Edrada, R. A.; Proksch, P.; Wray, V.; Witte, L. J . Nat Prod. 1997, 60, 716-718

(8) Duh, C.-Y.; Wang, S.-K.; Weng, Y.-L. Tetrahedron Lett. 2000, 41 1401-1404

(9) Duh, C.-Y.; Wang, S.-K.; Weng, Y.-L.; Chiang, M. Y.; Dai, C.-F. J Nat. Prod. 1999, 62, 1518-1521.

(10) Rao, M. R.; Venkatesham, U.; Venkateswarlu, Y.J . Nat. Prod. 1999, $62,1584-1585$

(11) Zhang, W.-H.; Williams, I. D.; Che, C.-T. Tetrahedron Lett. 2001, 42 $4681-4686$

(12) Duh, C.-Y.; Wang, S.-K.; Chu, M.-J .; Sheu, J .-H. J . Nat. Prod. 1998 $61,1022-1024$

(13) Geran, R. I.; Greenberg, N. H.; MacDonald, M. M. Schumacher, A. M.; Abbott, B. J . Cancer Chemother. Rep. 1972, 3, 1-91.

(14) Hou, R.-S.; Duh, C.-Y.; Chiang, M. Y.; Lin, C.-N. J . Nat. Prod. 1995, $58,1126-1130$

(15) Bowden, B. F.; Coll, J . C.; Mitchell, S. J .; Skelton, B. W.; White, A H. Aust. J . Chem. 1980, 33, 2737-2747.

(16) Iguchi, K.; Saitoh, S.; Yamada, Y. Chem. Pharm. Bull. 1989, 37, 2553-2554.

NP0400858 